\title{
Evaluating the Association of FAAH Common Gene Variation with Childhood, Adult Severe Obesity and Type 2 Diabetes in the French Population
}

\author{
Emmanuelle Durand ${ }^{a}$ Cécile Lecoeur ${ }^{\mathrm{a}} \quad$ Jérôme Delplanque ${ }^{\mathrm{a}}$ Michael Benzinou $^{\mathrm{a}}$ \\ Franck Degraeve $^{\mathrm{a}}$ Philippe Boutin $^{\mathrm{a}}$ Michel Marre $^{\mathrm{b}}$ Beverley Balkau ${ }^{\mathrm{c}}$ Guillaume Charpentier ${ }^{\mathrm{d}}$ \\ Philippe Froguel ${ }^{a, e} \quad$ David Meyre ${ }^{a}$ \\ a CNRS-8090, Institute of Biology, Pasteur Institute, Lille, \\ b Department of Endocrinology, Diabetology and Nutrition, Bichat-Claude Bernard University Hospital, Assistance Publique des Hôpitaux \\ de Paris, and INSERM U695, Paris 7 University, Paris, \\ ' INSERM U780-IFR69, Paris-Sud University, Villejuif, \\ dEndocrinology-Diabetology Unit, Corbeil-Essonnes Hospital, Corbeil-Essonnes, France \\ e Department of Genomic Medicine, Hammersmith Hospital, Imperial College London, UK
}

\section{Key Words}

Genetics - Obesity · Type 2 diabetes

\section{Summary}

Objective: The endocannabinoid pathway is involved in eating behavior and body weight regulation in both animals and humans. The association of a missense polymorphism (Pro129Thr) in FAAH gene with overweight/obesity has been recently questioned. Subjects and Methods: To evaluate the contribution of the $F A A H$ gene variation in polygenic obesity and type 2 diabetes mellitus (T2DM) in the French population, we investigated the entire FAAH locus. We selected and genotyped ten tagged single nucleotide polymorphisms (SNPs) in 635 obese children, 896 morbidly obese adults, 2,238 T2DM subjects and 1,340 control subjects, all of French European origin. Case control association tests were performed using logistic regression models. Results: Nominal evidences of association were observed for rs6429600, rs324419, rs324418, rs2295633, rs7520850 and risk for class III adult obesity $(0,001<\mathrm{p}<0.04)$. The rs324420 (Pro129Thr) was nominally associated with class III adult obesity (OR additive $=0.79(95 \% \mathrm{Cl} 0.67-0.93), \mathrm{p}=0.005 ; \mathrm{OR}_{\text {dominant }}=0.76$ (95\% Cl 0.63-0.92), $\mathrm{p}=0.005)$, Pro129 being the obesity risk allele. These associations did not remain significant after Bonferroni correction for multiple testing. There was no significant association between FAAH SNPs and risk for childhood obesity or T2DM. Conclusion: Our results in 5,109 subjects suggest that FAAH Pro129Thr polymorphism may modestly contribute to class III adult obesity in the French population. Further validation is needed to precise the role of this gene variant in obesity susceptibility background.

\section{Introduction}

Fatty acid amide hydrolase (FAAH) is the principal inactivating enzyme of endogenous cannabinoid degradation of the most important endocannabinoid ligand, anandamide, and hydrolyses other long fatty acids, especially 2-arachidonoylglycerol (2-AG) [1-3]. Endocannabinoids are lipid mediators derived from membrane phospholipids or triglycerides with complex effects on body weight and metabolic regulation [4]. It has been shown that both exocannabinoid and endocannabinoid are associated with an increased food intake and weight gain in animals through the central endocannabinoid pathway $[5,6]$.

Mice deficient in FAAH display reduced anxiety and ethanol sensitivity [7,8], and have reduced levels of the orexigenic peptide CART in several regions of the brain implicated in appetite control [9]. The FAAH gene is located in a region of linkage for dietary energy and nutrient intakes on chromosome 1 p33 in human populations [10]. In addition, FAAH mRNA expression in adipose tissue is negatively correlated with circulating endocannabinoid and visceral fat mass, and is increased in mature adipocytes compared with preadipocytes [11-13]. A functional missense polymorphism Pro129Thr has been associated with drug use [14-16] and with reduced cellular expression and activity of human FAAH in T lymphocytes and COS-7 cells [17]. In addition, the Pro129Thr polymorphism has been associated with overweight and obesity in a cohort of European and African ancestry, but this association was not confirmed in Asian [18] and was borderline associated with overweight in Danish population-based cohorts [19] but in the

\section{KARGER}

Fax +497614520714

Information@Karger.de

www.karger.com
(C) 2008 S. Karger GmbH, Freiburg

Accessible online at:

www.karger.com/ofa
Dr. David Meyre

CNRS-8090, Institute of Biology, Pasteur Institute

1 rue du Pr. Calmette, BP 245, 59019 Lille Cedex, France

meyre@good.ibl.fr 


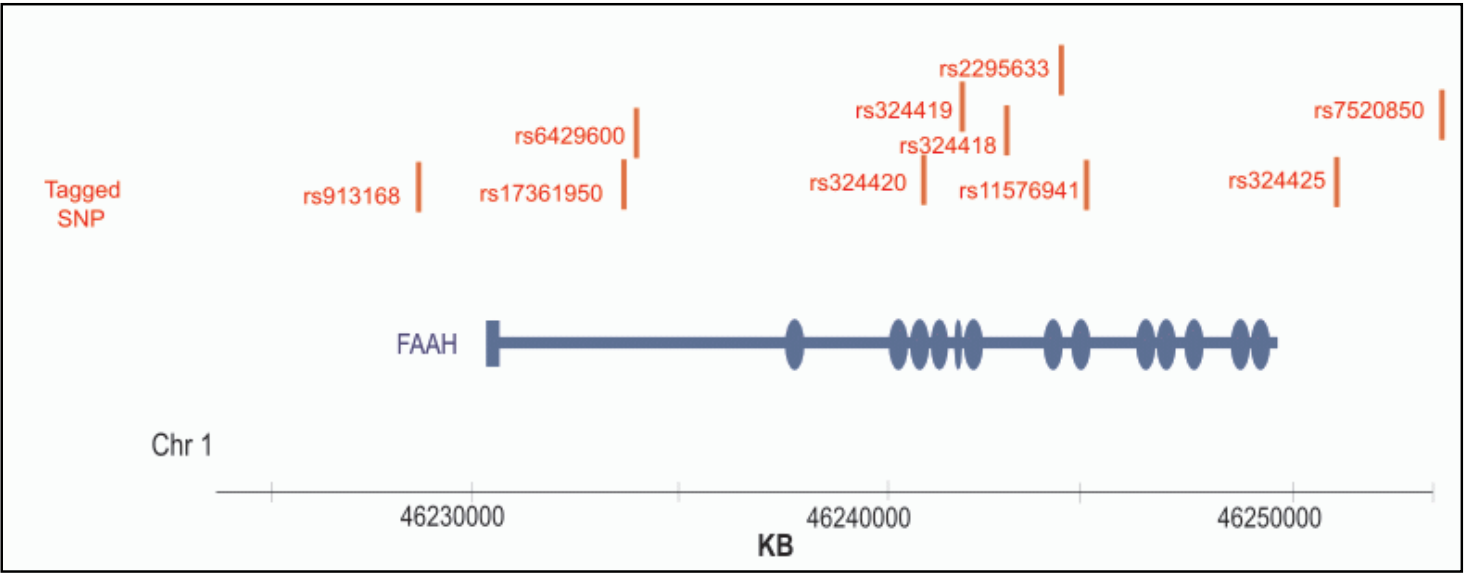

Fig. 1. Schematic representation of the $F A A H$ gene in the $30 \mathrm{~kb}$ studied interval and the tagged SNPs selected from Hap Map II (data Rel19/ phaseII Oct05, on NCBi B34 assembly).

\section{Tagging Procedure}

We selected tagged SNPs in the chromosome 1 region defining the $F A A H$ locus (chr1: 46,224,908_46,254,432), $5 \mathrm{~kb}$ upstream and $5 \mathrm{~kb}$ downstream flanking the gene. We used the Haploview program with the HapMap phase II database (October 2005) and selected SNPs with an $\mathrm{r}^{2}>0.8$ and a minor allele frequency $(\mathrm{MAF})>0.05$. Ten tagged SNPs that captured $100 \%$ of the haplotype representation within the $30 \mathrm{~kb} F A A H$ locus were chosen for the case control association study, including the previously observed associated SNP Pro129Thr amino acid change (fig. 1).

dominal adipose tissue of lean but not obese subjects. However the effect of the Pro129Thr functional polymorphism on the risk of type 2 diabetes mellitus (T2DM) has not been assessed to date. Our aim was to investigate the possible role of the whole $F A A H$ gene variations in susceptibility to polygenic severe obesity as well as to T2DM using a tagged single nucleotide polymorphism (SNP) approach in the French population.

\section{Subjects and Methods}

\section{Subjects}

Subjects in the case control studies were all French Caucasian, and an informed consent was signed by each subject before participating in the studies which were approved by local ethics committees.

The control subjects were recruited by the CNRS-UMR8090 or came from the general-population D.E.S.I.R. study [21]. We selected 1,340 unrelated adults, with BMI $<25 \mathrm{~kg} / \mathrm{m}^{2}$, age $\geq 40$ years, fasting glucose $<6.1 \mathrm{mmol} / 1$ and with no treatment for hyperglycemia (men/women 444/896; mean BMI $21.8 \pm 1.6 \mathrm{~kg} / \mathrm{m}^{2}$; mean age $55 \pm 10$ years).

The CNRS-UMR8090 recruited obese children. Childhood obesity was defined according to the European Childhood Obesity Group (ECOG) [22] as BMI exceeding the 97th percentile for gender and age in a French reference population. We selected 635 obese children (mean zBMI $4.3 \pm 1.2$; mean age $11 \pm 3$ years; men/women 296/339).

Obese adults were recruited by the CNRS-UMR8090 and by the Department of Nutrition of the Hotel Dieu Hospital in Paris. Class III obesity status was defined as BMI $\geq 40 \mathrm{~kg} / \mathrm{m}^{2}$ in adults. The obese adult group included 896 subjects (men/women 207/689) with a mean BMI of $47.5 \pm$ $7.6 \mathrm{~kg} / \mathrm{m}^{2}$ and a mean age of $45 \pm 12$ years.

The diabetic group was recruited by the Corbeil-Essonnes Hospital and by the CNRS-UMR8090. T2DM was defined as fasting plasma glucose $\geq 7.0 \mathrm{mmol} / \mathrm{l}$ and/or treatment by antidiabetic agents and age at onset of $\mathrm{T} 2 \mathrm{DM} \geq 45$ years old. We selected 2,238 subjects (men/women 1,327/911, mean age of $59 \pm 10$ years, mean age at onset of T2DM $48 \pm 10$ years and mean BMI $30.2 \pm 5.6 \mathrm{~kg} / \mathrm{m}^{2}$ ).

\section{SNP Genotyping}

Genotyping was performed using the Applied Biosystems SNPlex ${ }^{\mathrm{TM}}$ (Applied Biosystems, Foster City, CA, USA) technology based on the oligonucleotide ligation assay (OLA) combined with multiplex PCR target amplification. The chemistry of the assay relies on a set of universal core reagent kits and a set of SNP-specific ligation probes, allowing a multiplex genotyping of 48 SNPs simultaneously in a unique sample. Allelic discrimination is performed through capillary electrophoresis analysis using Applied Biosystems 3730xl DNA Analyzer and GeneMapper 3.7 software. The SNP rs913168 failed during the design process and was therefore genotyped using LightCycler ${ }^{\mathrm{TM}} 480$ technology (Roche Diagnostics, Basel, Switzerland). The conditions are available upon request. The rs 324420 was performed using the TaqMan ${ }^{\circledR}$ SNP Genotyping Assays on ABI 7900 (Applied Biosystems). The genotyping call rate was above 95\% for the ten SNPs. As a standard laboratory quality control measure, a random $10 \%$ of DNA samples were systematically re-genotyped, and we recorded a concordance rate of $100 \%$ for each SNP.

\section{Statistical Analysis}

Genotypic distributions were in Hardy-Weinberg equilibrium for all SNPs in the control subjects $(p>0.05)$. Case control association tests were performed using logistic regression models to take into account the effect of co-variables such as gender, age, and BMI. Logistic regression adjusted for gender and age was used for childhood and adult class III obesity traits. Logistic regression adjusted for gender, age, and BMI were used for T2DM trait. We tested additive, dominant and recessive modes of inheritance. For statistical power calculation we used the program QUANTO [23]. Using spectral decomposition, we estimated the total number of tests at 8.18 to applied for multiple comparisons to Bonferroni correction $(8.18$ SNPs $\times 3$ affection traits $\times 3$ genetic models $=73.6 ; p$ corrected $=0.00068$ ) [24].

We used linear regression models (corrected for gender and age) to assess the effect of SNP rs324420 on quantitative traits variation (BMI, fasting glucose and fasting insulin, waist circumference, triglycerides as well as HDL cholesterol and total cholesterol). 
Table 1. Genotype distribution of FAAH tagged SNP in lean normoglycemic controls, obese children, class III obese adults and T2DM subjects ${ }^{\mathrm{a}}$

\begin{tabular}{|c|c|c|c|c|c|c|c|c|c|c|}
\hline \multirow{3}{*}{$\begin{array}{l}\text { Taggeds } \\
\text { SNP }\end{array}$} & \multirow[t]{3}{*}{ Subjetcs } & \multicolumn{3}{|l|}{ Genotypes } & \multicolumn{6}{|c|}{ Adjusted odds ratio } \\
\hline & & \multirow[t]{2}{*}{11} & \multirow[t]{2}{*}{12} & \multirow[t]{2}{*}{22} & \multicolumn{2}{|c|}{ additive model } & \multicolumn{2}{|c|}{ recessive model } & \multicolumn{2}{|c|}{ dominant model } \\
\hline & & & & & $\begin{array}{l}\mathrm{p} \\
\text { value }\end{array}$ & OR $(95 \% \mathrm{CI})$ & $\begin{array}{l}\mathrm{p} \\
\text { value }\end{array}$ & OR $(95 \% \mathrm{CI})$ & $\begin{array}{l}\mathrm{p} \\
\text { value }\end{array}$ & OR (95\% CI) \\
\hline rs913168 & controls & $431(34.0)$ & $613(48.3)$ & 225 (17.7) & & & & & & \\
\hline \multirow[t]{3}{*}{$\mathrm{A}>\mathrm{G}$} & obese children & $228(37.4)$ & $280(45.9)$ & $102(16.7)$ & 0.24 & $0.92(0.80-1.06)$ & 0.65 & $0.94(0.73-1.22)$ & 0.18 & $0.87(0.71-1.06)$ \\
\hline & obese adults & $278(31.6)$ & $432(49)$ & $171(19.4)$ & 0.09 & $1.12(0.98-1.27)$ & 0.31 & $1.13(0.90-1.42)$ & 0.10 & $1.18(0.97-1.43)$ \\
\hline & T2DM subjects & $737(34.1)$ & $1,042(48.2)$ & $384(17.8)$ & 0.90 & $0.99(0.82-1.19)$ & 0.94 & $0.99(0.71-1.38)$ & 0.90 & $0.98(0.75-1.29)$ \\
\hline rs17361950 & controls & $671(51.2)$ & $528(40.3)$ & $112(8.5)$ & & & & & & \\
\hline \multirow[t]{3}{*}{$\mathrm{C}>\mathrm{T}$} & obese children & $315(50.0)$ & $265(42.1)$ & $50(7.9)$ & 0.79 & $1.02(0.88-1.18)$ & 0.70 & $0.93(0.66-1.32)$ & 0.57 & $1.06(0.87-1.28)$ \\
\hline & obese adults & $432(49.9)$ & $365(42.2)$ & $68(7.9)$ & 0.74 & $1.02(0.89-1.18)$ & 0.53 & $0.90(0.65-1.25)$ & 0.44 & $1.07(0.90-1.29)$ \\
\hline & T2DM subjects & $1,131(52.1)$ & $833(38.4)$ & $206(9.5)$ & 0.97 & $1.00(0.82-1.22)$ & 0.67 & $1.10(0.70-1.72)$ & 0.84 & $0.97(0.75-1.26)$ \\
\hline rs6429600 & controls & $736(56.5)$ & $487(37.4)$ & $79(6.1)$ & & & & & & \\
\hline \multirow[t]{3}{*}{$\mathrm{A}>\mathrm{G}$} & obese children & $349(57.0)$ & $221(36.1)$ & $42(6.9)$ & 0.76 & $1.02(0.87-1.20)$ & 0.48 & $1.15(0.78-1.70)$ & 0.98 & $1.00(0.82-1.22)$ \\
\hline & obese adults & $535(61.7)$ & $294(33.9)$ & $38(4.4)$ & 0.001 & $0.78(0.67-0.91)$ & 0.08 & $0.69(0.45-1.04)$ & 0.002 & $0.75(0.62-0.90)$ \\
\hline & T2DM subjects & $1,273(58.3)$ & $792(36.3)$ & $118(5.4)$ & 0.79 & $1.03(0.83-1.27)$ & 0.57 & $0.85(0.50-1.46)$ & 0.54 & $1.08(0.84-1.40)$ \\
\hline rs324420 & controls & $836(63.3)$ & $432(32.7)$ & $52(3.9)$ & & & & & & \\
\hline \multirow[t]{3}{*}{$\mathrm{C}>\mathrm{A}$} & obese children & $407(64.8)$ & $193(30.7)$ & $28(4.5)$ & 0.83 & $0.98(0.83-1.16)$ & 0.67 & $1.11(0.69-1.78)$ & 0.66 & $0.96(0.78-1.17)$ \\
\hline & obese adults & $602(67.7)$ & $262(29.5)$ & $25(2.8)$ & 0.005 & $0.79(0.67-0.93)$ & 0.20 & $0.72(0.43-1.19)$ & 0.005 & $0.76(0.63-0.92)$ \\
\hline & T2DM subjects & $1,404(64.3)$ & $696(31.9)$ & $84(3.8)$ & 0.72 & $1.04(0.83-1.30)$ & 0.65 & $0.86(0.45-1.65)$ & 0.54 & $1.09(0.83-1.41)$ \\
\hline rs324419 & controls & $920(70)$ & $365(27.8)$ & $29(2.2)$ & & & & & & \\
\hline \multirow[t]{3}{*}{$\mathrm{G}>\mathrm{A}$} & obese children & $466(74.1)$ & $150(23.8)$ & $13(2.1)$ & 0.13 & $0.86(0.71-1.04)$ & 0.84 & $0.93(0.48-1.81)$ & 0.10 & $0.83(0.67-1.04)$ \\
\hline & obese adults & $613(70.5)$ & $222(25.5)$ & $34(3.9)$ & 0.46 & $1.07(0.90-1.26)$ & 0.01 & $1.99(1.17-3.39)$ & 0.93 & $0.99(0.81-1.21)$ \\
\hline & T2DM subjects & $1,555(71.7)$ & $556(25.6)$ & $57(2.6)$ & 0.92 & $0.99(0.77-1.27)$ & 0.85 & $1.08(0.47-2.51)$ & 0.87 & $0.98(0.74-1.29)$ \\
\hline rs324418 & controls & $800(61)$ & $453(34.5)$ & $59(4.5)$ & & & & & & \\
\hline \multirow[t]{3}{*}{$\mathrm{T}>\mathrm{C}$} & obese children & $383(61.1)$ & $206(32.9)$ & $38(6.1)$ & 0.53 & $1.05(0.90-1.24)$ & 0.19 & $1.32(0.87-2.02)$ & 0.86 & $1.02(0.84-1.24)$ \\
\hline & obese adults & $561(64.4)$ & $276(31.7)$ & $34(3.9)$ & 0.04 & $0.85(0.72-0.99)$ & 0.72 & $0.92(0.58-1.45)$ & 0.02 & $0.80(0.67-0.97)$ \\
\hline & T2DM subjects & $1,333(61.5)$ & $739(34.1)$ & $97(4.5)$ & 0.54 & $1.07(0.86-1.33)$ & 0.82 & $0.93(0.51-1.69)$ & 0.40 & $1.12(0.86-1.45)$ \\
\hline rs2295633 & controls & $526(40.6)$ & $606(46.8)$ & $163(12.6)$ & & & & & & \\
\hline \multirow[t]{3}{*}{$\mathrm{C}>\mathrm{T}$} & obese children & $280(46.0)$ & $259(42.5)$ & $70(11.5)$ & 0.09 & $0.88(0.76-1.02)$ & 0.56 & $0.91(0.68-1.23)$ & 0.55 & $0.83(0.68-1.00)$ \\
\hline & obese adults & $378(44.7)$ & $375(44.4)$ & $92(10.9)$ & 0.02 & $0.86(0.74-0.98)$ & 0.18 & $0.82(0.62-1.09)$ & 0.03 & $0.82(0.68-0.98)$ \\
\hline & T2DM subjects & $916(43.4)$ & $937(44.3)$ & $260(12.3)$ & 0.92 & $0.99(0.82-1.20)$ & 0.80 & $0.95(0.65-1.40)$ & 0.97 & $1.00(0.77-1.30)$ \\
\hline rs11576941 & controls & $606(46.3)$ & $571(43.6)$ & $133(10.2)$ & & & & & & \\
\hline \multirow[t]{3}{*}{$\mathrm{G}>\mathrm{T}$} & obese children & $285(45.2)$ & $280(44.4)$ & $66(10.5)$ & 0.93 & $1.01(0.87-1.16)$ & 0.95 & $1.01(0.74-1.38)$ & 0.94 & $1.01(0.83-1.22)$ \\
\hline & obese adults & $391(45.1)$ & $388(44.8)$ & $88(10.1)$ & 0.58 & $1.04(0.91-1.19)$ & 0.86 & $0.97(0.72-1.31)$ & 0.41 & $1.08(0.90-1.29)$ \\
\hline & T2DM subjects & $973(45.0)$ & $959(44.3)$ & $232(10.7)$ & 0.60 & $0.95(0.79-1.15)$ & 0.96 & $1.01(0.67-1.52)$ & 0.46 & $0.91(0.70-1.17)$ \\
\hline rs324425 & controls & $1,199(91.5)$ & $108(8.2)$ & $3(0.2)$ & & & & & & \\
\hline \multirow[t]{3}{*}{$\mathrm{G}>\mathrm{A}$} & obese children & $570(90.9)$ & $52(8.3)$ & $5(0.8)$ & 0.31 & $1.17(0.86-1.60)$ & 0.10 & $3.34(0.78-14.21)$ & 0.49 & $1.12(0.80-1.58)$ \\
\hline & obese adults & 807 (92.4) & $63(7.2)$ & $3(0.3)$ & 0.36 & $0.86(0.63-1.18)$ & 0.54 & $1.66(0.32-8.58)$ & 0.28 & $0.83(0.59-1.16)$ \\
\hline & T2DM subjects & $2,009(92.0)$ & $172(7.9)$ & $2(0.1)$ & 0.80 & $1.06(0.67-1.69)$ & 0.74 & $0.55(0.02-18.65)$ & 0.76 & $1.08(0.67-1.75)$ \\
\hline rs7520850 & controls & $1,010(77.5)$ & $280(21.5)$ & $14(1.1)$ & & & & & & \\
\hline \multirow[t]{3}{*}{$\mathrm{G}>\mathrm{A}$} & obese children & $488(80.8)$ & $111(18.4)$ & $5(0.8)$ & 0.12 & $0.84(0.67-1.05)$ & 0.70 & $0.82(0.29-2.30)$ & 0.12 & $0.82(0.65-1.05)$ \\
\hline & obese adults & $662(77.1)$ & $175(20.4)$ & $22(2.6)$ & 0.19 & $1.14(0.94-1.38)$ & 0.005 & $2.79(1.37-5.69)$ & 0.56 & $1.06(0.86-1.32)$ \\
\hline & T2DM subjects & $1,662(76.8)$ & $473(21.9)$ & $28(1.3)$ & 0.77 & $1.04(0.79-1.38)$ & 0.52 & $0.64(0.16-2.54)$ & 0.65 & $1.07(0.79-1.45)$ \\
\hline
\end{tabular}

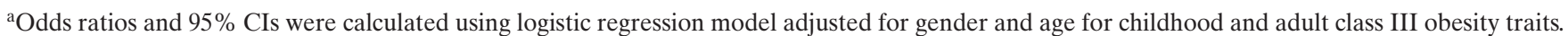
Logistic regression model adjusted for gender, age and BMI were used for T2DM trait.

\section{Results}

Ten tagged SNPs in the FAAH locus were successfully genotyped in 1,340 lean normoglycemic adults, 635 obese children, 896 class III obese adults and 2,238 T2DM subjects. Results of the case control study under both additive, dominant and recessive modes of inheritance are given in table 1 . There was no significant association between FAAH SNPs and risk for childhood obesity or T2DM. Nominal evidences of association were observed for $\mathrm{rs} 6429600\left(\mathrm{OR}_{\mathrm{additive}}=0.78(95 \% \mathrm{CI}\right.$ 
Table 2. Study of metabolic traits according to the $F A A H$ rs324420 (Pro129Thr) polymorphism ${ }^{\mathrm{a}}$

\begin{tabular}{|c|c|c|c|c|c|c|c|c|c|c|c|c|}
\hline \multirow[t]{2}{*}{ rs324420 (Pro129Thr) } & \multicolumn{3}{|l|}{$\mathrm{CC}$} & \multicolumn{3}{|l|}{$\mathrm{AC}$} & \multicolumn{3}{|l|}{ AA } & \multicolumn{3}{|l|}{$\mathrm{p}$ value } \\
\hline & number & mean & S.D. & number & mean & S.D. & number & mean & S.D. & additive & dominant & recessive \\
\hline BMI, $\mathrm{kg} / \mathrm{m}^{2}$ & 836 & 21.6 & 1.7 & 432 & 21.6 & 1.7 & 52 & 21.6 & 1.5 & 0.38 & 0.30 & 0.98 \\
\hline Fasting glucose, mmol/l & 836 & 5.04 & 0.42 & 431 & 5.01 & 0.44 & 52 & 5.03 & 0.45 & 0.40 & 0.38 & 0.81 \\
\hline Fasting insulin, mU/1 & 816 & 31.6 & 16.6 & 426 & 31.0 & 15.1 & 52 & 33.7 & 16.6 & 0.96 & 0.69 & 0.26 \\
\hline Waist circumference, $\mathrm{cm}$ & 813 & 74.7 & 7.5 & 424 & 73.6 & 7.7 & 50 & 75.6 & 7.2 & 0.58 & 0.31 & 0.35 \\
\hline HDL cholesterol, mmol/1 & 775 & 1.74 & 0.45 & 401 & 1.78 & 0.41 & 50 & 1.86 & 0.41 & 0.02 & 0.06 & 0.03 \\
\hline Total cholesterol, mmol/l & 775 & 5.58 & 0.94 & 401 & 5.55 & 0.91 & 50 & 5.84 & 1.01 & 0.26 & 0.59 & 0.05 \\
\hline Triglycerides, mmol/l & 775 & 0.89 & 0.46 & 401 & 0.85 & 0.40 & 50 & 0.86 & 0.38 & 0.64 & 0.59 & 0.98 \\
\hline
\end{tabular}

${ }^{\mathrm{a}} \mathrm{p}$ values were corrected for gender and age.

0.67-0.91), $\mathrm{p}=0.001 ; \mathrm{OR}_{\text {dominant }}=0.75(95 \%$ CI $0.62-0.90)$, $\mathrm{p}=0.002), \mathrm{rs} 324419\left(\mathrm{OR}_{\text {recessive }}=1.99(95 \%\right.$ CI $1.17-3.39)$, $\mathrm{p}=0.01), \operatorname{rs} 324418\left(\mathrm{OR}_{\text {additive }}=0.85\right.$ (95\% CI 0.72-0.99), $\mathrm{p}=$ $\left.0.04 ; \mathrm{OR}_{\text {dominant }}=0.80(95 \% \mathrm{CI} 0.67-0.97), \mathrm{p}=0.02\right), \mathrm{rs} 2295633$ $\left(\mathrm{OR}_{\text {additive }}=0.86(95 \%\right.$ CI $0.74-0.98), \mathrm{p}=0.02 ; \mathrm{OR}_{\text {dominant }}=$ $0.82(95 \%$ CI $0.68-0.98), \mathrm{p}=0.03), \mathrm{rs} 7520850\left(\mathrm{OR}_{\text {recessive }}=\right.$ $2.79(95 \%$ CI 1.37-5.69), $\mathrm{p}=0.005)$ and risk for class III obesity. The rs324420 (Pro129Thr) SNP was associated neither with childhood obesity nor with T2DM in our study. However, we found a nominally significant association between Pro129Thr polymorphism and class III adult obesity $\left(\mathrm{OR}_{\text {additive }}=0.79\right.$ (95\% CI 0.67-0.93), $\mathrm{p}=0.005 ; \mathrm{OR}_{\mathrm{dominant}}=0.76(95 \% \mathrm{CI}$ $0.63-0.92), \mathrm{p}=0.005)$, Pro129 being the obesity risk allele. These associations did not remain significant after multiple testing correction.

We then studied the effect of the SNP rs324420 (Pro129Thr) on metabolic traits in 1,340 lean normoglycemic adults (table 2). The lowest significance was observed between the rs 324420 SNP and HDL cholesterol (nominal $\mathrm{p}=0.02$ ) but is no more significant after Bonferroni correction $(1 \mathrm{SNP} \times 3$ genetic models $\times 7$ traits $=21$; corrected $=0.0024$ ).

\section{Discussion}

Our study is the first to cover the whole $F A A H$ gene haplotype structure in a large data set $(\mathrm{n}=5,109)$. Our results suggest that the FAAH Pro129Thr functional polymorphism [17] may modestly contribute to class III adult obesity, but not to childhood obesity or to T2DM in the French population. The full coverage of the FAAH locus using a tagged SNP approach did not reveal any additional gene variation significantly associated with the same affection traits. Our study was designed to detect an effect size of $1.35,1.30$ and 1.25 with a statistical power of $80 \%$ (MAF $0.1, p=0.05$ ) for childhood obesity, adult class III obesity and T2DM risk, respectively.

Regarding the Pro129Thr non-synonymous SNP, we were unable to confirm the initial association between Thr129 and obesity [18]. Indeed we found significant evidence of association between this polymorphism and class III adult obesity, but in opposite direction of the one reported by Sipe et al. [18] (obesity risk allele Pro129 in our design). Interestingly, Jensen et al. [19] found a nominal association of the Pro129 allele with risk of overweight/obesity in a large Danish population $(\mathrm{n}=5,801)$. This highlights the need for multiple replication to fully validate new disease susceptibility genes, as recently shown for the INSIG2 story [25-29]. It remains possible that severe familial forms of obesity may harbor a different genetic architecture than moderate forms of common obesity as studied by Sipe et al. [18]. However, Jensen et al. [19] were unable to replicate this association in a population-based Danish cohort.

A recent report has provided evidence that the hyperglycemic status could modulate FAAH mRNA level in subcutaneous abdominal adipose tissue of lean patients [20]. From these results, we hypothesized that FAAH gene variation could be involved in the etiology of T2DM. Our results based on 1,340 lean normoglycemic and 2,238 T2DM subjects exclude a major effect of $F A A H$ SNPs in the risk for T2DM.

In conclusion, a tagging SNP approach in the FAAH locus combined with a case control study of 635 obese children cases, 896 class III obese adults cases, 2,238 T2DM cases, and 1,340 controls suggest that FAAH Pro129Thr polymorphism may modestly contribute to class III adult obesity in the French population. Further validation is needed to precise the role of this gene variant in the obesity susceptibility background.

\section{Acknowledgments}

We thank the patients and families that participated in this study. This work was funded by the French MINEFI - Ministère de l'Industrie et des Finances - through the project 'Integrated Genomic Approaches for the Mmolecular Dissection of Cannabinoid Receptor 1 Signalling and of CB1 Antagonist Effects in Obesity and in the Metabolic Syndrome'.

\section{Disclosure}

The authors declared no conflict of interest.
308

Obesity Facts 2008;1:305-309
Durand/Lecoeur/Delplanque/Benzinou/ Degraeve/Boutin/Marre/Balkau/Charpentier/ Froguel/Meyre 


\section{References}

1 Fride E: Endocannabinoids in the central nervous system - an overview. Prostaglandins Leukot Essent Fatty Acids 2002;66:221-233.

2 Di Marzo V, Bifulco M, De Petrocellis L: The endocannabinoid system and its therapeutic exploitation. Nat Rev Drug Discov 2004;3:771-784.

3 Cravatt BF, Demarest K, Patricelli MP, Bracey MH, Giang DK, Martin BR, Lichtman AH: Supersensitivity to anandamide and enhanced endogenous cannabinoid signaling in mice lacking fatty acid amide hydrolase. Proc Natl Acad Sci U S A 2001; 98:9371-9376.

4 Giuffrida A, Beltramo M, Piomelli D: Mechanisms of endocannabinoid inactivation: biochemistry and pharmacology. J Pharmacol Exp Ther 2001;298: $7-14$.

5 Jamshidi N, Taylor DA: Anandamide administration into the ventromedial hypothalamus stimulates appetite in rats. Br J Pharmacol 2001;134:11511154.

6 Cota D, Marsicano G, Lutz B, Vicennati V, Stalla GK, Pasquali R, Pagotto U: Endogenous cannabinoid system as a modulator of food intake. Int J Obes Relat Metab Disord 2003;27:289-301.

7 Basavarajappa BS, Yalamanchili R, Cravatt BF, Cooper TB, Hungund BL: Increased ethanol consumption and preference and decreased ethanol sensitivity in female FAAH knockout mice. Neuropharmacology 2006;50:834-844.

8 Moreira FA, Kaiser N, Monory K, Lutz B: Reduced anxiety-like behaviour induced by genetic and pharmacological inhibition of the endocannabinoid-degrading enzyme fatty acid amide hydrolase (FAAH) is mediated by CB1 receptors. Neuropharmacology 2008;54:141-150.

$\checkmark 9$ Osei-Hyiaman D, Depetrillo M, Harvey-White J, Bannon AW, Cravatt BF, Kuhar MJ, Mackie K, Palkovits M, Kunos G: Cocaine- and amphetaminerelated transcript is involved in the orexigenic effect of endogenous anandamide. Neuroendocrinology 2005;81:273-282.

10 Collaku A, Rankinen T, Rice T, Leon AS, Rao DC, Skinner JS, Wilmore JH, Bouchard C: A genomewide linkage scan for dietary energy and nutrient intakes: the Health, Risk Factors, Exercise Training, and Genetics (HERITAGE) Family Study. Am J Clin Nutr 2004:79:881-886.

11 Engeli S, Bohnke J, Feldpausch M, Gorzelniak K, Janke J, Batkai S, Pacher P, Harvey-White J, Luft FC, Sharma AM, Jordan J: Activation of the peripheral endocannabinoid system in human obesity. Diabetes 2005;54:2838-2843.

12 Blüher M, Engeli S, Kloting N, Berndt J, Fasshauer M, Batkai S, Pacher P, Schon MR, Jordan J, Stumvoll M: Dysregulation of the peripheral and adipose tissue endocannabinoid system in human abdominal obesity. Diabetes 2006;55:3053-3060.

13 Kempf K, Hector J, Strate T, Schwarzloh B, Rose B, Herder C, Martin S, Algenstaedt P: Immune-mediated activation of the endocannabinoid system in visceral adipose tissue in obesity. Horm Metab Res 2007;39:596-600.

14 Flanagan JM, Gerber AL, Cadet JL, Beutler E, Sipe JC: The fatty acid amide hydrolase $385 \mathrm{~A} / \mathrm{A}$ (P129T) variant: haplotype analysis of an ancient missense mutation and validation of risk for drug addiction. Hum Genet 2006;120:581-588.
15 Sipe JC, Chiang K, Gerber AL, Beutler E, Cravatt BF: A missense mutation in human fatty acid amide hydrolase associated with problem drug use. Proc Natl Acad Sci U S A 2002;99:8394-8399.

16 Tyndale RF, Payne JI, Gerber AL, Sipe JC: The fatty acid amide hydrolase C385A (P129T) missense variant in cannabis users: studies of drug use and dependence in Caucasians. Am J Med Genet B Neuropsychiatr Genet 2007;144:660-666.

17 Chiang KP, Gerber AL, Sipe JC, Cravatt BF: Reduced cellular expression and activity of the P129T mutant of human fatty acid amide hydrolase: evidence for a link between defects in the endocannabinoid system and problem drug use. Hum Mol Genet 2004;13:2113-2119.

18 Sipe JC, Waalen J, Gerber A, Beutler E: Overweight and obesity associated with a missense polymorphism in fatty acid amide hydrolase (FAAH). Int J Obes (Lond) 2005;29:755-759.

19 Jensen DP, Andreasen CH, Andersen MK, Hansen L, Eiberg H, Borch-Johnsen K, Jorgensen T, Hansen T, Pedersen O: The functional Pro129Thr variant of the FAAH gene is not associated with various fat accumulation phenotypes in a populationbased cohort of 5,801 whites. J Mol Med 2007;85: 445-449.

20 Murdolo G, Kempf K, Hammarstedt A, Herder C, Smith U, Jansson PA: Insulin differentially modulates the peripheral endocannabinoid system in human subcutaneous abdominal adipose tissue from lean and obese individuals. J Endocrinol Invest 2007;30:RC17-21.

21 Balkau B: An epidemiologic survey from a network of French Health Examination Centres, (D.E.S.I.R.): epidemiologic data on the insulin resistance syndrome (in French). Rev Epidemiol Sante Publique 1996;44:373-375.

22 Poskitt EM: Defining childhood obesity: the relative body mass index (BMI). European Childhood Obesity group. Acta Paediatr 1995;84:961-963.

23 Gauderman WJ: Sample size requirements for matched case-control studies of gene-environment interaction. Stat Med 2002;21:35-50.

24 Nyholt DR: A simple correction for multiple testing for single-nucleotide polymorphisms in linkage disequilibrium with each other. Am J Hum Genet 2004;74:765-769.

25 Herbert A, Gerry NP, McQueen MB, Heid IM, Pfeufer A, Illig T, Wichmann HE, Meitinger T, Hunter D, Hu FB, Colditz G, Hinney A, Hebebrand J, Koberwitz K, Zhu X, Cooper R, Ardlie K, Lyon $\mathrm{H}$, Hirschhorn JN, Laird NM, Lenburg ME, Lange C, Christman MF: A common genetic variant is associated with adult and childhood obesity. Science 2006;312:279-283.

26 Dina C, Meyre D, Samson C, Tichet J, Marre M, Jouret B, Charles MA, Balkau B, Froguel P: Comment on 'A common genetic variant is associated with adult and childhood obesity'. Science 2007; 315:187; author reply 187 .

27 Rosskopf D, Bornhorst A, Rimmbach C, Schwahn C, Kayser A, Kruger A, Tessmann G, Geissler I, Kroemer HK, Volzke H: Comment on 'A common genetic variant is associated with adult and childhood obesity'. Science 2007;315:187; author reply 187.
28 Lyon HN, Emilsson V, Hinney A, Heid IM, LaskySu J, Zhu X, Thorleifsson G, Gunnarsdottir S, Walters GB, Thorsteinsdottir U, Kong A, Gulcher J, Nguyen TT, Scherag A, Pfeufer A, Meitinger T, Bronner G, Rief W, Soto-Quiros ME, Avila L, Klanderman B, Raby BA, Silverman EK, Weiss ST, Laird N, Ding X, Groop L, Tuomi T, Isomaa B, Bengtsson K, Butler JL, Cooper RS, Fox CS, O'Donnell CJ, Vollmert C, Celedon JC, Wichmann HE, Hebebrand J, Stefansson K, Lange C, Hirschhorn JN: The association of a SNP upstream of INSIG2 with body mass index is reproduced in several but not all cohorts. PLoS Genet 2007;3:e61.

29 Loos RJ, Barroso I, O'Rahilly S, Wareham NJ: Comment on 'A common genetic variant is associated with adult and childhood obesity'. Science 2007;315:187; author reply 187 .

30 Hinney A, Nguyen TT, Scherag A, Friedel S, Bronner G, Müller TD, Grallert H, Illig T, Wichmann HE, Rief W, Schäfer H, Hebebrand J: Genome wide association (GWA) study for early onset extreme obesity supports the role of fat mass and obesity associated gene (FTO) Variants. PLoS ONE 2007;2:e1361.

31 Liu YJ, Liu XG, Wang L, Dina C, Yan H, Liu JF, Levy S, Papasian CJ, Drees BM, Hamilton JJ, Meyre D, Delplanque J, Pei YF, Zhang L, Recker RR, Froguel P, Deng HW: Genome-wide association scans identified CTNNBL1 as a novel gene for obesity. Hum Mol Genet 2008;17:1803-1813.

32 Loos RJ, Lindgren CM, Li S, Wheeler E, Zhao JH Prokopenko I, Inouye M, Freathy RM, Attwood AP, Beckmann JS, Berndt SI, Jacobs KB, Chanock SJ, Hayes RB, Bergmann S, Bennett AJ, Bingham SA, Bochud M, Brown M, Cauchi S, Connell JM, Cooper C, Smith GD, Day I, Dina C, De S, Dermitzakis ET, Doney AS, Elliott KS, Elliott P, Evans DM, Sadaf Farooqi I, Froguel P, Ghori J, Groves CJ, Gwilliam R, Hadley D, Hall AS, Hattersley AT, Hebebrand J, Heid IM, Lamina C, Gieger C, Illig T, Meitinger T, Wichmann HE, Herrera B, Hinney A, Hunt SE, Jarvelin MR, Johnson T, Jolley JD, Karpe F, Keniry A, Khaw KT, Luben RN, Mangino M, Marchini J, McArdle WL, McGinnis R, Meyre D, Munroe PB, Morris AD, Ness AR, Neville MJ, Nica AC, Ong KK, O'Rahilly S, Owen KR, Palmer CN, Papadakis K, Potter S, Pouta A, Qi L, Kraft P, Hankinson SE, Hunter DJ, Hu FB, Randall JC, Rayner NW, Ring SM, Sandhu MS, Scherag A, Sims MA Song K, Soranzo N, Speliotes EK, Lyon HN, Voight BF, Ridderstrale M, Groop L, Syddall HE, Teichmann SA, Timpson NJ, Tobias JH, Uda M, Scheet P, Sanna S, Abecasis GR, Albai G, Nagaraja R, Schlessinger D, Ganz Vogel CI, Wallace C, Waterworth DM, Weedon MN, Willer CJ, Jackson AU, Tuomilehto J, Collins FS, Boehnke M, Mohlke KL, Wraight VL, Yuan X, Zeggini E, Hirschhorn JN, Strachan DP, Ouwehand WH, Caulfield MJ, Samani NJ, Frayling TM, Vollenweider P, Waeber G, Mooser V, Deloukas P, McCarthy MI, Wareham NJ, Barroso I: Common variants near MC4R are associated with fat mass, weight and risk of obesity. Nat Genet 2008;40:768-775. 